\title{
Differences in consumption of allochthonous DOC under limnic and estuarine conditions in a watershed
}

\author{
Johan Wikner ${ }^{1,2, *}$, Rocio Cuadros ${ }^{2}$, Mats Jansson ${ }^{3}$ \\ ${ }^{1}$ Umeả Marine Sciences Centre, Umeå University, Norrbyn, S-910 20 Hörnefors, Sweden \\ ${ }^{2}$ Department of Microbiology, Umeå University, S-901 87 Umeå, Sweden \\ ${ }^{3}$ Department of Ecology and Environmental Science, Umeả University, S-901 87 Umeả, Sweden
}

\begin{abstract}
A temporal study of the bacterial utilisation of allochthonous dissolved organic carbon (DOC) was performed in a lake and estuary situated in the same boreal watershed. A greater utilisation of allochthonous DOC was observed under estuarine as compared to limnic conditions. However, the bacterial biomass yield was not significantly different between the environments, indicating a lower growth efficiency on allochthonous DOC by the estuarine bacterioplankton. The largest fraction of the allochthonous DOC utilised $(20 \%)$ was observed under estuarine conditions and coincided with the spring flood. The utilisation of allochthonous DOC and bacterial biomass yield in the experimental bottles was limited by the availability of nitrogen or phosphorus in both environments. Our results showed that the major bacterial transformation of DOC occurred in the estuarine rather than the limnic environment, due to the shift in physicochemical milieu and bacterial assemblage. However, the estuarine bacteria also respired a greater fraction of the DOC utilised than their limnic counterparts
\end{abstract}

KEY WORDS: River - Limnic · Marine - Organic carbon - Bacteria · Seasonal - Utilisation · Growth efficiency

\section{INTRODUCTION}

Allochthonous dissolved organic carbon (DOC), also in the form of humic compounds, supports bacterioplankton growth in limnic and marine environments (Moran \& Hodson 1990, Carlsson \& Granéli 1993). In waters with low primary production and a high supply of terrigenous material, allochthonous carbon can be a major energy source for bacterioplankton (Tranvik 1988, Kuparinen et al. 1996), in spite of the fact that only about $10 \%$ of total allochthonous DOC is readily available to bacteria (Tranvik 1988, Moran \& Hodson 1990, Hobbie et al. 1996). Bacterial degradation of terrigenous compounds may, therefore, have pronounced effects on the bacterial production and carbon balance in lakes and estuaries. Studies on the bioavailability of bulk DOC are dominated by investigations from lakes or marine water, while investigations focusing on stream DOC are few (Leff \& Meyer 1991, Buffam et al. 1996, Hobbie et al. 1996, McKnight \& Aiken 1998). In most brown water streams and lakes, and in estuaries

\footnotetext{
•E-mail: johan.wikner@micro.umu.se
}

fed with brown freshwater, the major part of the DOC is allochthonous carbon which has been produced in and exported from the terrestrial parts of the catchment. This material is dominated by humic compounds (Thurman 1985, Pettersson 1992).

Stream transport dynamics of allochthonous DOC have been studied extensively (Thurman 1985, Ivarsson \& Jansson 1994b, McKnight \& Aiken 1998). Concentrations of allochthonous DOC in streams usually increase during high flow events. Studies on chemical alloch thonous DOC characteristics have indicated that high flow DOC is different from base flow DOC (Ivarsson \& Jansson 1994b, McKnight \& Aiken 1998) and that the DOC availability to bacterial degradation also depends on the hydrological situation (Leff \& Meyer 1991). It is therefore possible that bacterial utilisation of allochthonous DOC can vary over season, depending on DOC quality.

Soil export of humic compounds to stream water occurs more or less in the entire watershed and bacterial degradation in streams and lakes may be a continuous process. In theory, the degree of degradation in stream DOC should therefore increase downstream, while the portion of DOC which can be bacterially 
degraded should decrease proportionally (Leff \& Meyer 1991). The long water retention time in lakes compared with stream sections implies that a large part of surface water degradation and $\mathrm{CO}_{2}$ production takes place in lakes. The potential of stream water DOC to promote bacterial growth might therefore be higher when entering lakes higher up in a watershed compared to at the outlet to the sea. On the other hand, estuaries offer a chemical and physical environment that is different from freshwater (e.g. higher ionic strength), which may influence the bioavailability of dissolved terrigenous compounds. It is known that organic material aggregates in saline environments (Sholkowitz 1976, Forsgren et al. 1996), and that organic aggregates can be more susceptible to bacterial degradation than DOC (Tranvik \& Sieburth 1989).

To study the availability of allochthonous DOC to lacustrine and estuarine bacteria we conducted a study on how lake and estuarine bacteria consume riverine DOC sampled from lake and estuary inlets at different times of the year. The main objectives were to see if there were differences in bacterial consumption of inflowing allochthonous DOC: (1) between a lake and an estuary that are parts of the same drainage system, and (2) at different times of the year, particularly between high flow and low flow conditions.

The study was carried out in the River Öre catchment in northern Sweden. The River Öre flows through one lake, Lake Örträsket, and ends in the Öre Estuary about $100 \mathrm{~km}$ downstream. This enabled a comparison of the transformation of DOC in a lake and estuary within the same watershed, where temporal variations and absolute concentrations of DOC were similar.

\section{MATERIALS AND METHODS}

Field sampling. The River Ore catchment in northern Sweden is $2940 \mathrm{~km}^{2}$ Approximately $20 \%$ of the catchment consists of mires and most of the remainder is coniferous forest. Mean annual precipitation is $650 \mathrm{~mm}$ and the mean annual total organic carbon concentration at the river mouth is about $800 \mu \mathrm{M}$ (Ivarsson \& Junsson 1994a). The river is non-regulated, has no major sources of industrial or municipal waste water and has a natural seasonal flow pattern. The river mouth in the Ore Estuary is situated in the northern part of the Bothnian Sea (The Baltic Sea).

Water samples were taken from the River Öre, $2 \mathrm{~km}$ upstream from the river mouth and from the inlet to Lake Orrträsket $\left(64^{\circ} 10^{\prime} \mathrm{N}, 18^{\circ} 55^{\prime} \mathrm{E}\right)$. Lake Örträsket is situated in the main channel, halfway along the river course and approximately $100 \mathrm{~km}$ upstream from the estuary. The area of Lake Örträsket is $7 \mathrm{~km}^{2}$, the mean

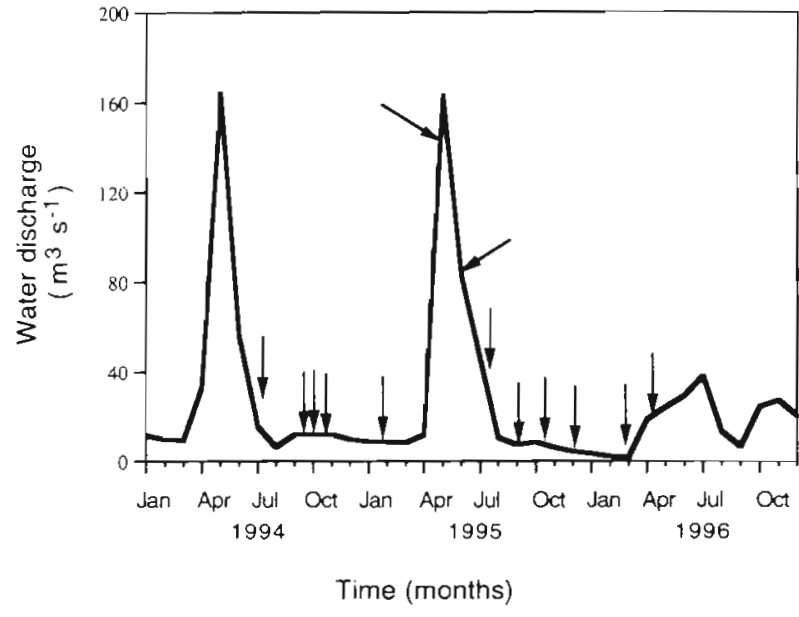

Fig. 1. Discharge in the Öre River during the investigation period. Arrows denote sampling dates in accordance with data presented in Figs. 2, 3, 4 \& 5

depth $22 \mathrm{~m}$ and the theoretical residence time $100 \mathrm{~d}$. For the Lake Örträsket dilution cultures, the inoculum was taken from the epilimnion using a $2 \mathrm{~m}$ long, $50 \mathrm{~mm}$ i.d. Plexiglas tube.

The Ore Estuary is surrounded by an archipelago. has an area of $50 \mathrm{~km}^{2}$ and a mean depth of $16 \mathrm{~m}$. The theoretical residence time is $10 \mathrm{~d}$. For the Öre Estuary dilution cultures the inoculum was collected at a depth of $4 \mathrm{~m}$ from coastal station NB1 $\left(63^{\circ} 30^{\prime} \mathrm{N}, 19^{\circ} 49^{\prime} \mathrm{E}\right)$, which has a central position in the estuary.

The sampling dates and the flow regime during the investigation period are shown in Fig. 1 . Only 1 clear spring flood event occurred during the study, partly due to an unusually low water flow during spring 1996. Each arrow in the graph indicates samplings taken the same week from the inlets of the lake and estuary.

An experiment to test if the difference in utilisable DOC (UDOC) between the environments was an effect of increased ionic strength and bacterial inoculum, rather than a difference in DOC quality, was performed separately. Four true replicate samples from $2 \mathrm{~km}$ upstream from the river mouth were inoculated with limnic and estuarine bacteria, respectively. The estuarine treatment also included addition of brackish water salt medium to 4 psu as described below. Enrichment, incubation and measurements of DOC and bacterial biomass were also similar to the seasonal study.

Experimental design. Utilisation of DOC was measured by recording net change in DOC at the plateau phase in dilution cultures with a bacterial inoculum (Tranvik 1988). One unenriched and one nutrientenriched bottle were used. Samplings were performed during different seasons on 12 occasions between April 1994 and May 1996 from the 2 different environments. 
The coefficient of variation for 4 true replicates (i.e. 4 parallel batch cultures) was estimated from a separate spatial survey at 13 stations from the headwater to the river mouth in the River Öre watershed.

All polycarbonate bottles, filters, filtration equipment, etc. used during the sample processing were carefully washed with $10 \% \mathrm{HCl}$ and rinsed with copious amounts of Millipore ${ }^{(1)}$ Milli-Q water before each experiment. For sterile filtration, the water was filtered through a $0.2 \mu \mathrm{m}$ polysulphone membrane filter Supor 200 (Gelman ${ }^{3}$ ) at $<200 \mathrm{~mm} \mathrm{Hg}$. These filters caused no change in the DOC concentration (Norrman 1993).

During $0.2 \mu \mathrm{m}$ filtration a few bacteria and most bacteriophages can pass through the filters (Tranvik 1988, Stockner et al. 1989, Moran \& Hodson 1990, authors' unpubl. obs.). To increase the reduction of microorganisms, water samples were serially filtered 3 times through fresh $0.2 \mu \mathrm{m}$ Gelman Supor ${ }^{(*)}$ filters. This process generally took 2 to $4 \mathrm{~h}$. DOC measurements during the preparation of sterile filtered water showed that the difference in DOC concentration between each filtration was not statistically significant $(p<0.05$, t-test).

Water sampled (1 l) from the River Öre was adjusted to the salinity of the Öre estuary $(4 \%$ ) with $40 \mathrm{ml}$ 'Brackish water medium' $(100 \times)$. A $100 \times$ concentration of this medium contained: $7.9 \mathrm{~g}$ of $\mathrm{NaCl}, 0.22 \mathrm{~g}$ of $\mathrm{KCl}$, $0.99 \mathrm{~g}$ of $\mathrm{Na}_{2} \mathrm{SO}_{4}$ per $100 \mathrm{ml}$ (autoclaved at $121^{\circ} \mathrm{C}$ for $30 \mathrm{~min}$ ). To $79 \mathrm{ml}$ of this solution $18 \mathrm{ml}$ of an autoclaved solution containing $94 \mathrm{~g} \mathrm{l}^{-1}$ of $\mathrm{MgCl}_{2}$ and $30 \mathrm{ml}$ of a solution containing $109 \mathrm{~g} \mathrm{l}^{-1}$ of $\mathrm{CaCl}_{2}$ was added.

The inoculum was prepared by gentle gravity filtration 3 times through 3 different $0.6 \mu \mathrm{m}$ polycarbonate filters (MSI $I^{(1)}$ ) and added to the cultures to give a 10 fold dilution of the in situ concentration (sampling sites given above). Cultures prepared by single filtrations (as commonly used in DOC studies) frequently resulted in infections by flagellates, and an earlier plateau phase after about $100 \mathrm{~h}$ (data not shown). Cultures of 1 to $1.5 \mathrm{l}$ were incubated in polycarbonate bottles in the dark at $15^{\circ} \mathrm{C}$ for all samples. The length of the incubation experiments varied between 6 and $15 \mathrm{~d}$, depending on the time period necessary to reach the plateau phase. The cultures were monitored every 2 nd day for bacterial numbers, and the DOC concentration was determined in the beginning and at the maximum of the plateau phase in each culture.

As the DOC concentrations did not differ significantly before and after the filtration procedure (data not shown), the multiple filtrations did not significantly contaminate the samples with exogenous DOC or significantly reduce the natural DOC concentration. The DOC samples before and after filtration were therefore pooled $(n=4)$ to estimate the initial DOC concentration in the bioassays
Nutrient additions. Nitrogen (final conc. $\mathrm{NH}_{4} \mathrm{Cl}$, $300 \mu \mathrm{M}$ ) and phosphorus (final conc. $\mathrm{Na}_{2} \mathrm{PO}_{4}, 1.2 \mathrm{mM}$ ) were added to the cultures in order to obtain nutrient replete conditions in the enriched treatment. This would ensure that the bacteria were carbon limited. The high $\mathrm{PO}_{4}{ }^{3-}$ concentration chosen was therefore also aimed to account for the potential binding to abundant $\mathrm{Fe}^{3+}$ and other interfering cations in the river water.

Bacterial abundance. Samples for determination of bacterial abundance were preserved with particle-free formaldehyde at a final concentration of $4 \%$ and stored at $4^{\circ} \mathrm{C}$ until slide preparation. Within $1 \mathrm{wk}$ preserved samples of 2 to $5 \mathrm{ml}$ were stained for $5 \mathrm{~min}$ with acridine orange, filtered onto black $0.2 \mu \mathrm{m}$ polycarbonate $\mathrm{MSI}^{(}$filters, and mounted in paraffin oil on a microscope slide (Hobbie et al. 1977). Cells were counted in an epifluorescence microscope (Zeiss Universal) with a Neofluar $100 \times$ oil immersion objective and 1.25 ocular. At least 30 fields and 300 cells were counted for each sample.

Biomass calculation. Cell sizes were determined by image-analysed fluorescence microscopy using a cooled, slow-scan charge-coupled device camera, CCD (C4742 Hamamatsu) (Blackburn et al. 1998). An Axioplan microscope was used with a Neofluar $100 x$ objective. Images were acquired by focusing an image and exposing the CCD chips. Images were calibrated in the camera controller and transmitted to a digital frame grabber program (IQBase ver. 1.20). Image analysis was initiated from processing and analysis software (LabView ver. 2.0).

The length (l) and area (A) of 70 to 500 focused cells were recorded. Cell volumes $(V)$ were calculated according to the formula $V=4 \pi r^{3} / 3+(1-2 r) \pi r^{2}$ which approximates the form of each cell by assuming it is a cylinder with 2 hemispherical caps. Biovolumes were converted to bacterial carbon biomass using data by a carbon-to-volume function (Norland 1993): $m_{\mathrm{b}}=$ $0.12 V^{0.7}$, where $m_{\mathrm{b}}$ is the carbon content of the bacterial cell (pg cell $\left.{ }^{-1}\right)$, and $V$ is the bacterial volume $\left(\mathrm{\mu m}^{3}\right)$, taking into account that the carbon density increased with decreasing cell volume (Simon \& Azam 1989).

The coefficient of variation for the bacterial biomass yield $\left(Y_{b}\right)$ was determined from the spatial survey of the watershed described above to be $30 \%( \pm$ SD 10$)$. Similarily, as discussed above, the corresponding $95 \%$ confidence interval amounted to $\pm 47 \%(n=4)$. Therefore, in the present study only the whole study period, or high versus low flow periods, could be compared with sufficient confidence.

Bacterial growth efficiency. The bacterial growth efficiency ( $B G E$ ) was calculated by the formula

$$
B G E=\frac{Y_{\mathrm{b}}}{\partial D O C} \times 100
$$


where $Y_{\mathrm{b}}$ is the bacterial biomass maximum yield in the plateau phase of the growth curve and $\partial D O C$ is the net change in the concentration of DOC in the experimental bottles during the same time period.

Bacterial growth rates. The bacterial growth rate $(\mu)$ was calculated as the slope of the ln transformed bacterial numbers versus time during the exponential growth phase. The lag portion of the curves was omitted and the end of logarithmic growth was defined by the highest value before the curve reached the plateau phase.

Nutrient analyses. Determination of nutrient concentrations was carried out in the field samples at each sampling. No nutrient measurements were done in the dilution cultures. $\mathrm{NH}_{4}-\mathrm{N}, \mathrm{NO}_{2}-\mathrm{N}, \mathrm{NO}_{3}-\mathrm{N}$, total nitrogen, $\mathrm{PO}_{4}$-P and total phosphorus were analysed with an autoanalyser (Technicon TRAACS 800) according to standard operating procedures at the Dept of Marine Chemistry, Umeå Marine Sciences Centre. Original methods were as described by Grasshoff et al. (1983). From the samples $50 \mathrm{ml}$ was transferred to acid-rinsed polypropylene test tubes (Nunc $\left.{ }^{(}\right)$) and kept at $+4^{\circ} \mathrm{C}$ until further analysis (less than $24 \mathrm{~h}$ ). Dissolved organic nitrogen (DON) was determined by the difference between measurements of total nitrogen in samples filtered through $0.2 \mu \mathrm{m}$ cellulose acetate filters (Sartorius ${ }^{\circledR}$ ) and the sum of inorganic nitrogen. Dissolved organic phosphorus (DOP) was calculated by subtraction as total phosphorus in a $0.2 \mu \mathrm{m}$ filtered sample minus the phosphate concentration. The samples for total nutrients were autoclaved $\left(30 \mathrm{~min}, 130^{\circ} \mathrm{C}\right)$ in an oxidation solution of $10 \mathrm{~g} \mathrm{~K}_{2} \mathrm{~S}_{2} \mathrm{O}_{8}$ and $6 \mathrm{~g} \mathrm{H}_{3} \mathrm{BO}_{3}$ in $200 \mathrm{ml}$ of $0.375 \mathrm{M} \mathrm{NaOH}$ prior to analysis of nitrogen oxides. The detection limits for $\mathrm{PO}_{4}-\mathrm{P}, \mathrm{NH}_{4}-\mathrm{N}$ and $\mathrm{NO}_{3}-\mathrm{N}$ were $0.01,0.07$, and $0.05 \mu \mathrm{M}$ respectively.

Dissolved organic carbon (DOC). Samples for the determination of DOC were filtered through a $0.2 \mu \mathrm{m}$ Gelman Supor ${ }^{(1)}$ filter using a sterile syringe (Plastipak $^{(3)}$ ) and filterholders (Millipore ${ }^{(2)}$ within 4 h of sampling according to Norrman (1993). Filtered water $(7.5 \mathrm{ml})$ was collected in polypropylene test tubes (Falcon ${ }^{\otimes}, 15 \mathrm{ml}$ ) and immediately acidified with $100 \mu \mathrm{l}$ of $1.2 \mathrm{M} \mathrm{HCl}$ to remove inorganic carbon. The samples were stored in a refrigerator $\left(+4^{\circ} \mathrm{C}\right)$ until analysis. All material coming into contact with the samples was carefully rinsed with $1 \mathrm{M} \mathrm{HCl}$ and washed with ultrapure water (Millipore Milli-Q). DOC was measured by the high temperature catalytic oxidation method (HTCO) using a Shimadzu TOC-5000 instrument with platinum coated $\mathrm{Al}_{2} \mathrm{O}_{3}$ granulates as catalyst. The instrument has been subjected to international intercalibration (Peltzer et al. 1996). The HTCO analysis was done within $1 \mathrm{wk}$ of sampling in all cases, and most frequently within $48 \mathrm{~h}$. Samples of $150 \mu \mathrm{l}$ were injected in triplicate showing standard deviations of 0 to $2 \%$. The detection limit of the DOC method was
$17 \mu \mathrm{M}$. A Milli-Q blank was run after each 10 samples, and a system blank was calculated by averaging these Milli-Q results. The system blank was then subtracted from each sample result. Calculation of carbon concentrations was made using potassium hydrogen phtalate as standard substance. An in-house reference seawater $\left(3.8 \mathrm{mg} \mathrm{l}^{-1}\right)$ was run several times during each sample batch for quality control.

$\partial D O C$ was calculated from the replicates before $(\mathrm{n}=$ 4 ) and after $(n=2)$ incubation. The \pm SD was calculated by taking the square root of the sum of the variances.

From the separate spatial survey of DOC consumption $(\partial D O C)$, using quadruplicate true replicate samples from 13 stations along the same watershed ( $N$ = $13, n=4$ ), we calculated an average coefficient of variation of $29 \%$ ( \pm SD 23). No dependence on treatment or station could be demonstrated. This $\pm \mathrm{SD}$ applied on the seasonal study would mean a $95 \%$ confidence interval of $\pm 46 \%$, assuming 4 replicates. Reducing the confidence interval to half the value would require 16 true replicates for each treatment, which is not feasible with present methodology. Therefore the statistical analysis of differences in $2 D O C$ between stations and treatments was made for the whole study period, or as a comparison between high and low flow periods.

Data processing and statistics. Before parametric tests were applied the data series were tested for normality by histogram and probability plots. Data clearly deviating from normality were tested by methods not requiring normal distribution. Pair-wise $t$-test was the main analytical method comparing the environments for normal distributed data, while the Wilcoxon signed rank test was applied where normal assumptions were not met. All statistical analyses in this study were performed with the software SYSTAT ${ }^{(1)}$ ver, 5.2.

\section{RESULTS}

\section{Bacterial bioassay}

A typical growth curve of a bacterial bioassay is shown in Fig. 2. The initial concentration of bacteria was 0.5 to $3 \times 10^{5}$ cells $\mathrm{ml}^{-1}$ and the plateau phase more than an order of magnitude higher in the enriched samples was reached after about $1.3 \mathrm{~d}$. The corresponding time period for unenriched samples was much shorter. The relatively long time period required to reach a plateau phase was at least partly associated with the 3 -fold serial filtration of both the river medium and inoculum employed in our study.

The relatively long incubation times, without apparent flagellate infection (i.e. as observed during bacterial counting), also allowed a lower sampling frequency (i.e. $48 \mathrm{~h}$ sampling intervals). This was, as is shown in 


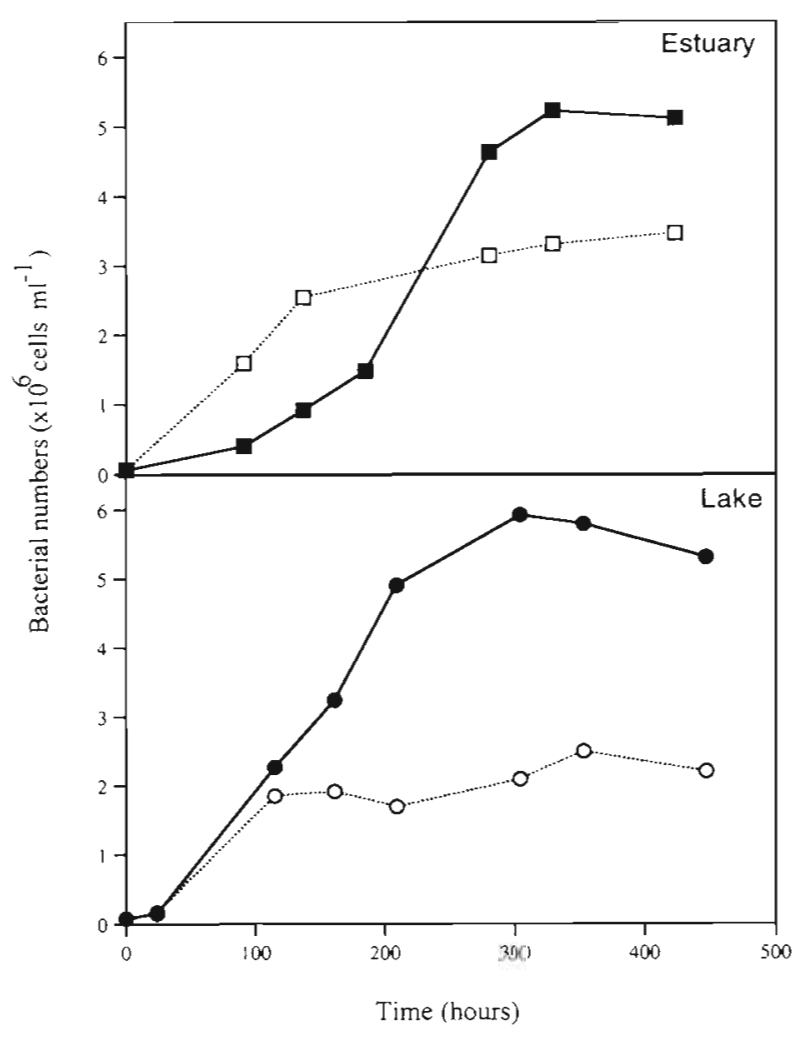

Fig. 2. Typical growth curves in bioassay experiments under limnic and estuarine conditions, respectively (performed May 1996). Filled symbols: enriched samples; open symbols: unenriched. The yield was operationally determined from a clear plateau phase or as the maximum value when a stable plateau was not reached

Fig. 2, sufficient for identification of the plateau phase and calculation of the bacterial specific growth rate.

In separate control cultures without inoculum no significant decrease in DOC could be demonstrated (data not shown). Also, in a few cases where POC was determined, differences between start and end in the cultures were too small to explain the observed differences in DOC by a transfer of DOC to POC (data not shown). Therefore, the interpretation of the $\partial D O C$ estimates was based on the assumption that all loss was due to bacterial respiration.
The potential growth by estuarine bacteria on autochthonous estuarine DOC in the inoculum was investigated in a control experiment, where an estuarine sample was diluted 1:10 with brackish water salt medium. The biomass yield on DOC in the inoculum was less than $1 / 10$ of the yield on total DOC in a parallel sample with allochthonous riverine DOC as the main DOC source. Therefore allochthonous riverine DOC was the major source of carbon and energy utilised in our cultures with estuarine inoculum.

\section{Physical and chemical characteristics}

Average temperature and $\mathrm{pH}$ did not clearly differ between the upper and lower part of the river (Table 1). The $\mathrm{C} / \mathrm{P}_{\text {org }}$ ratio was slightly higher at the river mouth compared to the lake inlet, and was dependent on both higher DOC and lower DOP concentrations. The median concentration of dissolved inorganic phosphorus (DIP) for the period was about 3 times higher at the river mouth. Also the dissolved inorganic nitrogen (DIN) concentration was about 2fold higher than the value upstream from the lake.

The data indicated an average molar $\mathrm{C}: \mathrm{N}: \mathrm{P}$ ratio in the riverine organic fraction of $3150: 94: 1$. The coefficient of variation $( \pm \mathrm{CV}$ ) showed that DOP, and consequently the $\mathrm{C} / \mathrm{P}$ org ratio, was the most variable component of the dissolved organic matter. This was especially true close to the river mouth.

\section{Consumption of allochthonous DOC by lake and marine bacteria}

The absolute consumption of riverine DOC was on average higher under estuarine conditions in both enriched and unenriched samples (Fig. 3). The median DOC consumption by estuarine bacteria was 44 and $36 \mu \mathrm{M}$ in enriched and unenriched samples respectively, while corresponding values for the lake were significantly lower (paired $t$-test, $p<0.01$, Tables $2 \& 3$ ). In fact, the net changes in DOC measured in the lake

Table 1. Physical and chemical characteristics of the river water at the entrance to the lake (River $r_{L}$ ) and $2 \mathrm{~km}$ upstream from the estuary $\left(\right.$ River $\left._{E}\right)$, respectively. The number of samples was 10 to 12 for all variables, except temperature in the lake, which was based on 7 measurements. Median ratios were calculated from the ratios at each sampling date

\begin{tabular}{|lcccccccccc|}
\hline & $\begin{array}{c}\text { Temp } \\
\left({ }^{\circ} \mathrm{C}\right)\end{array}$ & $\mathrm{pH}$ & $\begin{array}{c}\text { DOC } \\
(\mu \mathrm{M})\end{array}$ & $\begin{array}{c}\text { DON } \\
(\mu \mathrm{M})\end{array}$ & $\begin{array}{c}\text { DOP } \\
(\mu \mathrm{M})\end{array}$ & ${\mathrm{C} / \mathrm{P}_{\text {org }}}$ & C/Norg & $\begin{array}{c}\text { DIN } \\
(\mu \mathrm{M})\end{array}$ & $\begin{array}{c}\text { DIP } \\
(\mu \mathrm{M})\end{array}$ & $\begin{array}{c}\text { N/P } \\
\text { inor }\end{array}$ \\
\hline River median & 6.0 & 6.76 & 496 & 16 & 0.20 & 2472 & 33 & 1.2 & 0.055 & 32 \\
CV $(\%)$ & 99 & 3.0 & 34 & 41 & 64 & 34 & 28 & 100 & 99 & 118 \\
River median & 5.0 & 6.88 & 575 & 16 & 0.14 & 3618 & 36 & 2.1 & 0.17 & 37 \\
CV $(\%)$ & 72 & 4.9 & 25 & 18 & 116 & 46 & 14 & 94 & 124 & 59 \\
\hline
\end{tabular}




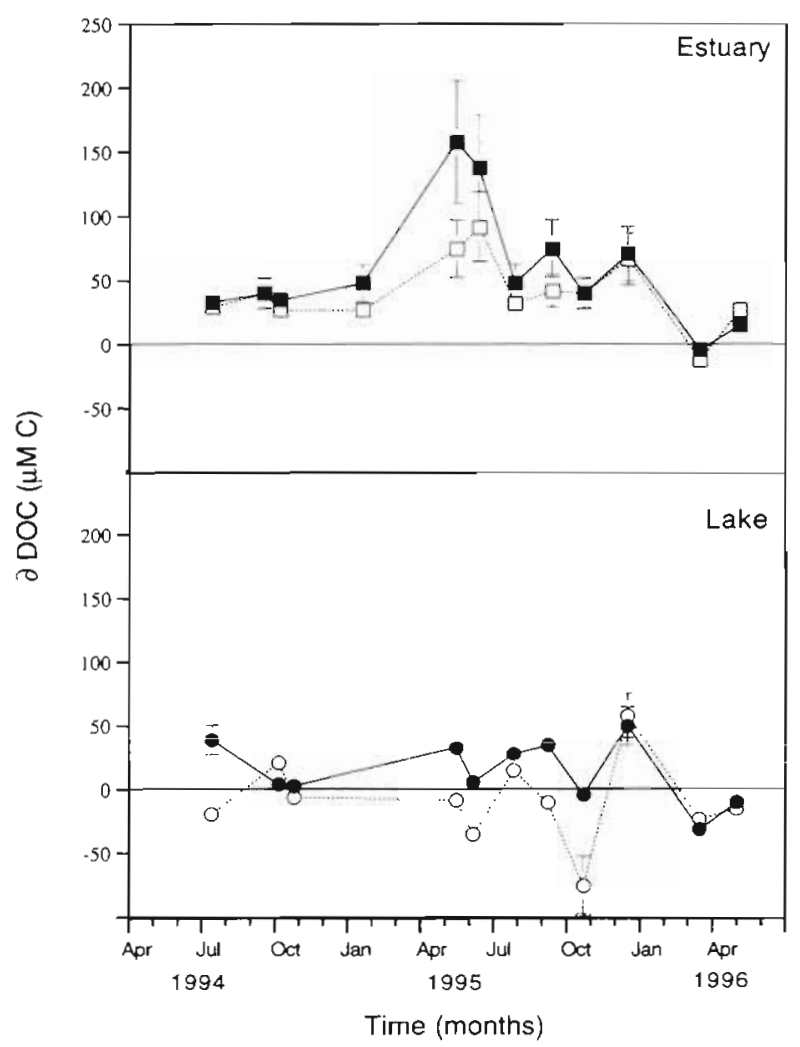

Fig. 3. Annual variation in net change in DOC in the bacterial dilution cultures in the lake and estuary, respectively. Filled symbols: samples enriched with ammonium and phosphate; open symbols: unenriched control cultures. Error bars represent the estimated summed $\pm \mathrm{SD}$ for true replicate dilution cultures $(n=4)$, estimated in a separate experiment $(\mathrm{N}=13)$ strated as significantly higher as compared with other seasons. No similar clear increase in DOC consumption could be demonstrated under limnic conditions in connection with the spring flood in either treatment.

\section{Fraction of utilisable DOC}

The fraction of UDOC can be calculated as

$$
U D O C=\frac{\partial D O C}{[D O C]}
$$

where $\partial D O C$ is the absolute amount of utilised DOC and $[D O C]$ the DOC concentration. UDOC reflects the quality of the bulk DOC from the aspect of its bioavailability in a short-term perspective.

The associations of UDOC were similar to those of $\partial D O C$, as the variation and absolute values of the in situ DOC concentration did not vary significantiy between the sampling locations (Fig. 4). The UDOC under estuarine conditions showed significantly higher values than in the lake $(\mathrm{p}<0.05$, Tables $2 \& 3)$. Furthermore, the utilisable pool of DOC (UDOC) under estuarine conditions was significantly higher in enriched samples during the spring flood (average $18 \%)$ than either before $(5.3 \%)$ or after $(6.1 \%$, independent $t$-test $\mathrm{p}<0.02)$ this high-flow period. The UDOC values during the spring flood in the estuary were also significantly higher than during the same period in the lake (both treatments, $\mathrm{p}<0.01$ ). Individual UDOC values varied between undetectable values and $20 \%$ under estuarine conditions, the highest were at the detection level, resulting in some samples showing non-significant differences.

Enrichment resulted in a greater utilisation of DOC under both estuarine and lake conditions (paired $t$-test, $p<0.05)$. This effect was most marked during the period April until October 1995 in both environments (paired $t$ test, $p<0.05$ ). No significant differences between enriched and unerrichcd samples taken during the winter season could be demonstrated.

The 2 samples from the estuarine environment taken at the peak of the 1995 spring flood showed significantly higher consumption of DOC $(148 \mu \mathrm{M}$ C) than before $(39 \mu \mathrm{M} \mathrm{C})$ or after (41 $\mu \mathrm{M} C$ ) the peak for the enriched treatment only ( $t$-test, $\mathrm{p}<0.04$ ). Corresponding unenriched samples during the spring flood could not be demon-
Table 2. Statistical observations for data (enriched/unenriched cultures) from (A) the Öre Estuary and (B) Lake Örträsket from 1994 to 1996. Net change in DOC in dilution cultures ( $\partial D O C)$, the utilised fraction of the DOC (UDOC), bacterial biomass yield $\left(Y_{\mathrm{b}}\right)$, bacterial growth efficiency $(B G E)$ and bacterial specific growth rate $(\mu)$ are shown

\begin{tabular}{|c|c|c|c|c|c|}
\hline & $\begin{array}{l}2 D O C \\
(\mu M C)\end{array}$ & $\begin{array}{c}\text { UDOC } \\
(\%)\end{array}$ & $\begin{array}{l}B G E \\
(\%)\end{array}$ & $\begin{array}{c}Y_{b} \\
(\mu M C)\end{array}$ & $\underset{\left(h^{-1}\right)}{\mu}$ \\
\hline \multicolumn{6}{|c|}{ (A) Öre Estuary } \\
\hline Median & $44 / 36$ & $8.0 / 6.3$ & $12 / 11$ & $5.1 / 4.3$ & $0.020 / 0.021$ \\
\hline Maximum & $158 / 92$ & $20 / 12$ & $37 / 27$ & $15 / 11$ & $0.041 / 0.034$ \\
\hline ivintinituñ̄i & $-4 ;-12$ & $-1.2:-3.5$ & $3.2 ! 1.6^{\mathrm{d}}$ & $1.4 / 1.5$ & $0014 / 0014$ \\
\hline $\pm S D$ & $47 / 27$ & $6.0 / 4.1$ & $41 / 15$ & $4.1 / 2.6$ & $0.009 / 0.005$ \\
\hline n & 12 & 12 & 12 & 12 & 12 \\
\hline \multicolumn{6}{|c|}{ (B) Lake Örträsket } \\
\hline Median & $6 /-10$ & $0.8 /-1.8$ & $28 /-11$ & $8.1 / 2.3$ & $0.015 / 0.016$ \\
\hline Maximum & $50 / 58$ & $9.7 / 11$ & $85 / 24$ & $17 / 8.5$ & $0.035 / 0.040$ \\
\hline Minimum & $-31 /-75$ & $-9.7 /-18$ & $-53^{d} /-97$ & $2.1 / 0.11$ & $0.010 / 0.004$ \\
\hline$\pm \mathrm{SD}$ & $25 / 34$ & $5.2 / 7.2$ & $132 / 37$ & $5.1 / 2.9$ & $0.008 / 0.012$ \\
\hline $\mathrm{n}$ & 11 & 11 & 11 & 11 & 11 \\
\hline
\end{tabular}




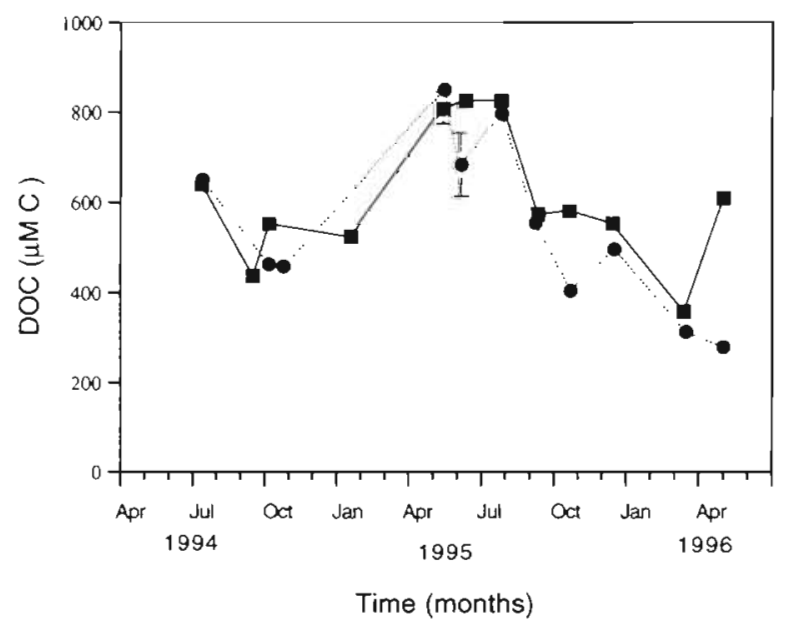

Fig. 4. DOC concentration in situ at the sampling sites in the Öre River $2 \mathrm{~km}$ upstream from the river mouth (⿴) and at the inflow in Lake Örträsket (). Error bars show the $\pm 1 \mathrm{SD}$ of the DOC estimates $(n=2)$

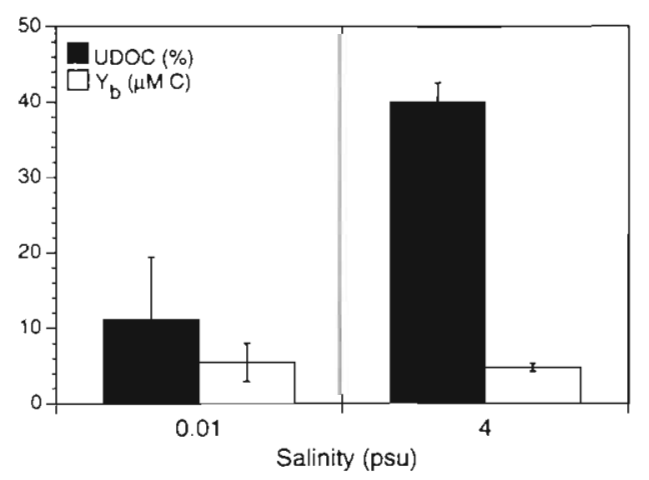

Fig. 5. Fraction of utilisable riverine DOC (UDOC) and bacterial biomass yield $\left(Y_{\mathrm{b}}\right)$ under estuarine $(4 \mathrm{psu})$ and limnic (0.01 psu) conditions. The DOC was collected at the sampling site $2 \mathrm{~km}$ upstream the river mouth in both treatments. The estuarine treatment was inoculated with estuarine bacterioplankton and the limnic treatment with lake bacterioplankton. Error bars show the $95 \%$ confidence interval of the 4 replicate batch cultures with the seasonal study no significant difference in bacterial biomass yield could be demonstrated between the treatments, suggesting a markedly lower growth efficiency under estuarine conditions.

\section{Bacterial biomass yield}

Enrichment resulted in higher bacterial biomass yield $\left(Y_{b}\right)$ in both environments, with the positive response being twice as large in the lake (Fig. 6, Wilcoxon rank test, $\mathrm{p}<0.03$ ). As for the consumption of DOC, the enrichment effect was most marked during the summer period in the estuarine samples (April and October, $p<0.05$ ), while being higher during the whole study period under limnic conditions $(p<0.01)$. This indicated that the accumulation of bacterial biomass from allochthonous DOC was hampered by a shortage of phosphorus or nitrogen, and was most marked in the lake environment.

The average bacterial biomass yield was not significantly different between the estuary and the lake, neither for enriched nor for unenriched samples (Fig. 6, Wilcoxon rank test). Thus, the significantly higher DOC consumption under estuarine conditions was not accompanied by a higher biomass yield, which indicated a lower growth efficiency under estuarine conditions.

\section{Bacterial growth efficiency}

Calculating the bacterial growth efficiency ( $B G E$ ) for all individual samples from bacterial biomass yield $Y_{\mathrm{b}}$ and net DOC change suggested higher growth yields in enriched samples in the lake (median $28 \%$ ) than in the estuary (12\%, Table 2$)$. However, the differences between either locations or treatments were not signif- value during the spring flood (Table 2). Under limnic conditions corresponding values varied between negative and $16 \%$, without clearly higher values during the spring flood.

Increased salinity and an estuarine inoculum promoted 4 times higher bacterial utilisation of DOC $(40 \%, 313 \mu \mathrm{M})$ than the treatment with riverine inoculum without salt addition (Fig. 5, $\mathrm{n}=4, \mathrm{p}<0.05$ ). This showed that the difference in UDOC in the seasonal study was not just a consequence of differences in DOC quality between the environments (in situ DOC concentration $783 \mu \mathrm{M}$ ). Also in agreement
Table 3. Compilation of statistical results from pair-wise tests for differences between the environments or treatments. A paired $t$-test was performed for consumption of DOC (DDOC) and the fraction of utilisable DOC (UDOC). Distribution free Wilcoxon's rank test was performed on bacterial biomass yield $\left(Y_{b}\right)$, bacterial growth efficiency $(B G E)$ and bacteridi specific grow th rate $(\mu)$. Significant differences at $p<0.05$ (in bold)

\begin{tabular}{|lccccc|}
\hline & JDOC & $Y_{\mathrm{b}}$ & UDOC & $\mu$ & $B G E$ \\
\hline Lake vs estuary & & & & & \\
Enriched & $\mathbf{p}=\mathbf{0 . 0 0 6}$ & $\mathrm{p}=0.86$ & $\mathbf{p}=\mathbf{0 . 0 0 1}$ & $\mathrm{p}=0.20$ & $\mathrm{p}=0.39$ \\
Unenriched & $\mathbf{p}=\mathbf{0 . 0 0 2}$ & $\mathrm{p}=0.18$ & $\mathbf{p}=\mathbf{0 . 0 0 2}$ & $\mathrm{p}=0.53$ & $\mathrm{p}=0.59$ \\
Enriched vs unenriched & & & & \\
Lake & $\mathbf{p}=\mathbf{0 . 0 4}$ & $\mathbf{p = 0 . 0 0 4}$ & $\mathbf{p}=\mathbf{0 . 0 2}$ & $\mathrm{p}=0.96$ & $\mathrm{p}=0.11$ \\
Estuary & $\mathbf{p}=\mathbf{0 . 0 3}$ & $\mathbf{p = 0 . 0 3}$ & $\mathbf{p}=0.06$ & $\mathrm{p}=0.75$ & $\mathrm{p}=0.25$ \\
\hline
\end{tabular}




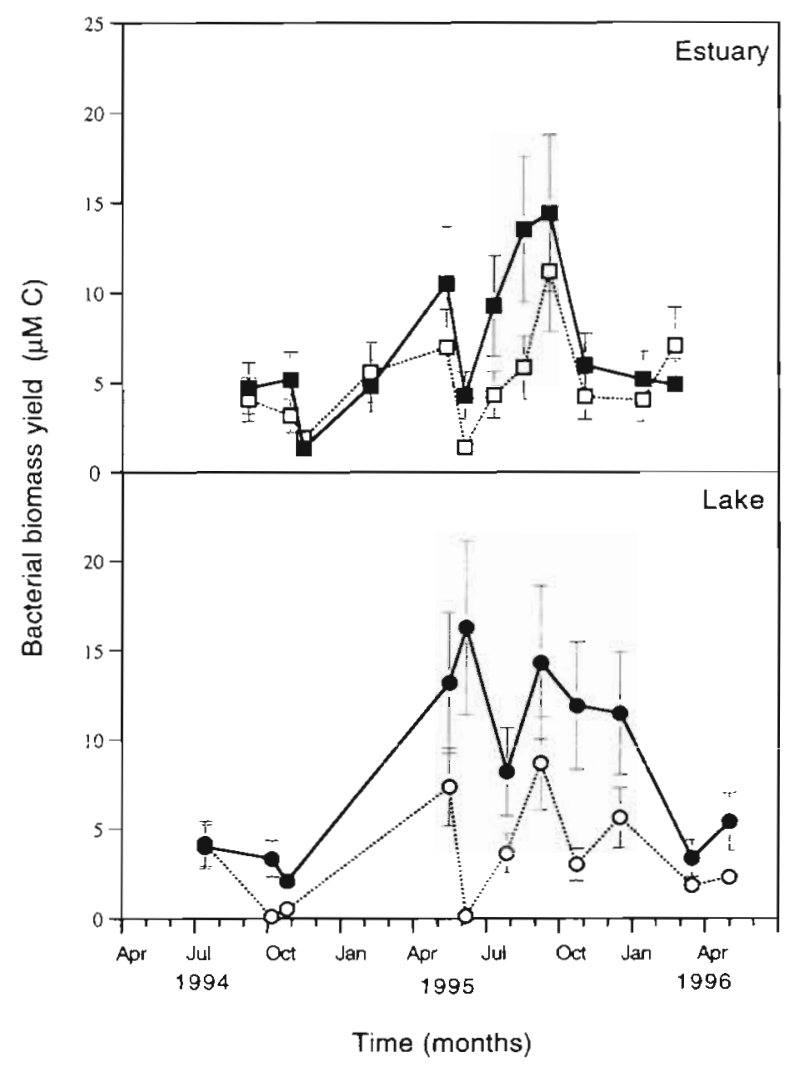

Fig. 6. Annual variation in bacterial biomass yield in the Öre Estuary and Lake Örträsket. Filled symbols: samples enriched with ammonium and phosphate; open symbols: unenriched control cultures. Error bars represent the estimated summed \pm SD for true replicate dilution cultures $(n=4)$, estimated in a separate experiment $(\mathrm{N}=13)$

icant according to a Wilcoxon rank test (Table 3). This was probably due to the high intra-annual variability in $B G E$ during the study period, which was found most frequently under limnic conditions (cf. \pm SD, Table 2). The limnic unenriched samples showed an average $B G E$ value below zero. The latter is not realistic and may derive from the imprecision of the DOC method, occasionally resulting in samples showing net increase in DOC, usually under limnic conditions. Given the high variance of $\partial D O C$ and $Y_{\mathrm{b}}$, the estimates of $B G E$ based on the ratio of the 2 parameters were poor due to high variability in the nominatnr and denominator (cf. 'Materials and methods').

\section{Specific bacterial growth rate}

The specific bacterial growth rate, $\mu$, calculated from the slope of the growth curves indicated about 30\% higher values in the estuary than in the lake, independent of enrichment or not (Table 2). However, this difference was not statistically significant (Table 3). The median growth rate in the lake corresponded to a generation time of $1.4 \mathrm{~d}$, while the maximum rates corresponded to doublings of less than a day $(17 \mathrm{~h})$. Maximum values were similar in the 2 environments irrespective of treatment, while the minimum values observed were lower in the lake.

\section{DISCUSSION}

In the context of the hypothesis that DOC is ageing during its passage through a watershed, our results suggested that this was not an important factor for determining the difference in utilisation of riverine DOC between a lake and an estuary in the same watershed. This conclusion does not contradict that the availability of DOC may vary within the limnic environment as found for the Ogeechee River by Leff \& Meyer (1991). Instead, the increase in salinity and/or a shift in bacterial species compositions in the estuarine environment had a major influence on increasing the bioavailability of riverine DOC. This utilisation was however not accompanied with an increased $Y_{b}$, suggesting a lower growth efficiency under estuarine conditions.

The conclusion above was based on the significantly higher DOC utilisation under estuarine rather than limnic conditions, whether enriched or not (Fig. 3, Tables 2 \& 3). A similar higher relative utilisation of DOC $(U D O C)$ in nutrient replete samples suggested that the higher consumption was not merely a consequence of a higher DOC concentration (Tables $2 \& 3$, Fig. 4). The complementary experiment, based on DOC from the same site in the river mouth (Fig. 5), supported the results from the seasonal study. This experiment further excluded that a difference in DOC quality between the lake and estuary was the main cause of the difference in UDOC. The high ionic strength in the estuarine samples could have been the cause of this increased bioavailability, although the presence of different bacterial species cannot be excluded as an explanation. Increased ionic strength is known to affect coiling of organic polymers and reduce their hydrodynamic radius (Stumm \& Morgan 1996). Increased salinity also promotes flocculation (Sholkowitz 1976), although not common in our cultures, which may enhance bacterial degradation (Tranvik \& Sieburth 1989). In support of our finding, stimulation by increased salinity of the bacterial utilisation of limnetic DON has also been observed (R. Stepanauskas, University of Lund, pers. comm.).

Information on differences in species composition and enzymology between the bacterial communities in the lake and estuary is lacking, and we cannot exclude that characteristics of the bacterial assemblages also 
influenced the observed differences in DOC utilisation. To discriminate between a pure salinity or bacterial effect is a delicate problem. This is because the performance of bacteria from marine and limnic environments are expected to be intimately associated with the ionic strength of their medium due to physiological requirements.

Despite the higher consumption of DOC under estuarine conditions, $Y_{\mathrm{b}}$ did not vary significantly between the environments (Fig. 6, Tables 2 \& 3). This implied that the growth efficiencies of lake bacterioplankton (median value $28 \%$ ) were higher than for estuarine bacterioplankton (12\%). As the same result was obtained in the experiment when only riverine DOC from the river mouth was used, the increased salinity and/or differences in bacterial metabolism were the main explanation for the lower growth efficiency, rather than a down river ageing of DOC. Whether this was due to a lower quality of DOC, made available by higher ionic strength, or an evolved feeding strategy of estuarine bacteria to produce chemical bound energy, cannot be determined from this study. Taken together, the results of carbon utilisation and biomass production thereby indicated that the estuarine environment was more important for the biological transformation of terrigenous $\mathrm{DOC}$ to $\mathrm{CO}_{2}$ than the largest lake in the watershed.

The estuarine growth efficiency obtained in this study $(12 \%)$ was clearly lower than earlier estimates of growth on estuarine DOC in the Öre Estuary (27\%, Zweifel et al. 1993). One potential cause of this difference was that DOC sampled from the estuary contains a larger fraction of readily available phytoplankton exudes than riverine DOC sampled in this study. The growth efficiencies we obtained were also lower than the average of estuarine environments reported in the literature (34\%, del Giorgio et al. 1997). We suggest that the lower BGE observed in our study was partly due to the different experimental design offering only allochthonous DOC to the estuarine bacterial assemblage. The median $B G E$ in the enriched limnic samples in our study $(28 \%)$ was higher than in the estuary, although not significantly different due to high variability. The limnic values compared well with values used in the literature (20\%, del Giorgio et al. 1997).

In an ecosystem perspective, it is vital to understand how the bioavailability of allochthonous DOC varies with season and flow regime. The highest utilisation of allochthonous DOC under estuarine conditions coincided with the spring flood (average $18 \%$ ), when about half (46\%, Forsgren 1994) of the annual riverine DOC discharge occurs. An important consequence of this observation is that allochthonous DOC discharged during the spring flood may be quantitatively and qualitatively more important to the marine ecosystem than during the rest of the year. The lack of an increase in UDOC at the unexpected poor flow rate during spring 1996 was still internally consistent with a positive association between UDOC and flow rate. In Lake Örträsket no statistically significant increase in bacterial utilisation of allochthonous DOC was observed during the spring flood. This observation disagrees with other results from Lake Örträsket demonstrating increased bacterial production in the lake in connection with spring flood events (Jansson et al. 1998). The fact that only 1 high flow episode was represented by 1 experiment in our study make conclusions on the availability of spring flood DOC to bacteria uncertain.

The fraction of riverine DOC used (UDOC) in our study compared relatively well with average values of streams, estuarine and oceanic environments reported in a comprehensive review by Søndergaard \& Middleboe (1995). However, the specific consumption of allochthonous riverine DOC by lake and estuarine bacteria has not often been studied previously in the literature (i.e. Hobbie et al. 1996). It is therefore interesting to compare the size of the utilisable fraction of allochthonous riverine carbon with some corresponding values for autochthonous DOC from different aquatic environments.

The highest utilisation reported in our limited compilation of DOC studies appeared to coincide with spring bloom events, or when challenging estuarine bacterioplankton with riverine DOC (Table 4). These events represent situations with marked amounts of pristine DOC, not previously exposed to extensive degradation in the lake or estuarine environments. High turnover rates and utilisation of DOC (23 to $42 \%$ ) were reported by Kirchman et al. (1991) during a spring bloom in the north Atlantic, as well as by Amon \& Benner (1994) during a diatom bloom in the Gulf of Mexico. These were in accordance with the prevailing view that pristine phytoplankton DOC contains a larger fraction of UDOC than the bulk DOC pool. However, the studies designed to investigate the consumption of riverine DOC by estuarine bacteria (Hobbie et al. 1996, present study) showed higher maximum values than a study using bulk estuarine DOC (7\%, Zweifel et al. 1993). According to our estimates the major part of the allochthonous DOC entering the marine system should be assigned UDOC values of $18 \%$ (average during spring flood). Although the insight that bulk DOC contain sub-fractions with different bioavailability is not novel, this comparison suggests that riverine terrestrial DOC during the spring flood (with $80 \%$ humic content), previously considered as a refractive component, has a larger bioavailable fraction than the bulk estuarine DOC. Therefore, estimates of the utilisation of bulk estuarine DOC may underestimate the turnover of pristine allochthonous DOC entering the marine 
Table 4. Estimates of the utilised fraction of the DOC pool (UDOC) from different aquatic environments. Sampled seasons and origin of DOC are also shown

\begin{tabular}{|c|c|c|c|c|}
\hline Environment & Season & DOC source & $U D O C(\%)$ & Source \\
\hline Stream & Winter & Autochtonous & $1-9^{a}$ & Leff \& Meyer (1991) \\
\hline Lake & Summer & Autochtonous & 9.5 & Tranvik (1988) \\
\hline Lake & Spring-summer & Autochtonous & $5-9$ & Sondergaard et al. (1995) \\
\hline Lake & All seasons & Allochthonous & $0-11^{b}$ & Present study \\
\hline Estuary & Spring-summer & Allochthonous ${ }^{c}$ & $6-17$ & Hobbie et al (1996) \\
\hline Estuary & All seasons & Allochthonous & $0-20^{b}$ & Present study \\
\hline Estuary & Summer-Fall & Autochthonous & $1-7$ & Zweifel et al. (1993) \\
\hline Ocean & Spring bloom & Autochthonous & $23-42$ & Kirchman et al. (1991) \\
\hline Ocean & Spring bloom & Autochthonous & $9-52$ & Amon \& Benner (1994) \\
\hline Ocean/coastal & Fall & Autochthonous $^{d}$ & $3-11$ & Moran \& Hodson (1994) \\
\hline Ocean & All seasons & Autochthonous & $7-9$ & Carlson \& Ducklow (1996) \\
\hline \multicolumn{5}{|c|}{ 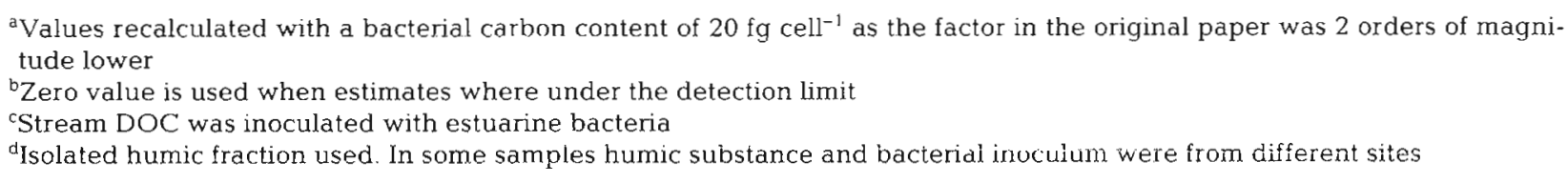 } \\
\hline
\end{tabular}

ecosystem. This result contributes to the emerging evidence that terrestrial organic matter, containing substantial amounts of humic matter, can supply energy and materials to aquatic food chains in both limnic and coastal marine ecosystems (Tranvik 1988, Moran \& Hodson 1990, Findlay et al. 1991, Hessen 1992, Carlsson \& Granéli 1993).

The utilisation of DOC in the limnic environment showed a median value of $0.6 \%$ in unenriched samples. This was clearly lower than the average for 27 lakes (median 14\%) reviewed by (Søndergaard \& Middleboe 1995). Using a bacterial growth efficiency of $30 \%$ would still give a low UDOC value based on the bacterial biomass yield $(2.7 \%$, Table $2 \mathrm{~B})$. The lower values in our study may possibly be due to the use of allochthonous DOC instead of the bulk lake DOC and the sampling at different seasons.

Enrichment with nitrogen and phosphorus promoted higher consumption of DOC, as well as higher $Y_{b}$, than in unenriched samples (Figs. $3 \& 5$ ). Similar results were obtained by Zweifel et al. (1993), studying the autochthonous DOC of the Öre Estuary, and Jansson et al. (1996) in studies on limiting factors for bacterial production in Lake Örträsket. Carlson \& Durklow (1996) also observed nutrient limitation to be of importance when studying the consumption of oceanic DOC. In the Amazon River carbon rather than nitrogen or phosphorus limitation has been reported (Benner et al. 1995). As our experimental bottles lacked zooplankton, and thus active remineralisation, caution should be used to apply our result to natural conditions. However, the observed shortage of nitrogen or phosphorus imply that the utilisation of DOC, at least periodically, was limited by the supply of mineral nutrients.
Acknowledgements. This study would not have been possible without the skilled analysis of DOC and nutrients by Dr Erik Lundberg and co-workers at the unit of Marine Chemistry, Umed Marine Sciences Centre. The use of the facilities of UMSC was also appreciated. Funding for this project was provided by the Swedish Natural Science Research Council (NFR), partly within the priority area 'Dynamics of Global Biogeochemical Cycles'

\section{LITERATURE CITED}

Amon RMW, Benner R (1994) Rapid cycling of high-molecular weight dissolved organic matter in the ocean. Nature 369: $549-552$

Benner R, Opsahl S, Chin-leo G, Richey JE, Forsberg BR (1995) Bacterial carbon metabolism in the Amazonas River system. Limnol Oceanogr 40:1262-1270

Blackburn N, Hagström $\AA$, Wikner J, Cuadros Hansson R, Bjørnsen P (1998) Automatic counting, measurement, morphology, and growth rate estimates of bacteria in aquatic samples by image analysis. Appl Environ Microbiol 64:3246-3255

Buffam I, Köhler S, Jonsson A, Jansson M, Bishop K (1996) Photochemical and microbial processing of dissolved organic matter in streams and soil water. Biol Bull 191:330-331

Carlson CA. Ducklow HW (1996) Growth of bacterioplankton and consumption of dissolved organic carbon in the Sargasso Sea Aquat Microb Erol 10:69-85

Carlsson P, Granéli E (1993) Availability of humic bound nitrogen for coastal plankton. Estuar Coast Shelf Sci 36: $433-447$

del Giorgio P, Cole J, Cimbleris A (1997) Respiration rates in bacteria exceed phytoplankton production in unproductive aquatic systems. Nature 385:148-151

Findlay S, Pace ML, Lints D, Cole JJ, Caraco NF, Peierls B (1991) Weak coupling of bacterial and algal production in a heterotrophic ecosystem: the Hudson river estuary. Limnol Oceanogr 36:268-278

Forsgren G (1994) Sedimentation of iron, phosphorus and organic carbon in limnetic and estuarine environments in 
the Öre river system, northern Sweden. Thesis, Dept of Physical Geography, Umeå University

Forsgren G, Jansson M. Nilsson P (1996) Aggregation and sedimentation of iron, phosphorus and organic carbon in experimental mixtures of freshwater and estuarine water Estuar Coast Shelf Sci 43:259-268

Grasshoff K, Ehrhardt M, Kremling K (1983) Methods of seawater analysis. Verlag Chemie, Weinheim

Hessen DO (1992) Dissolved organic carbon in a humic lake: effects on bacterial production and respiration. Hydrobiologia 229:115-123

Hobbie JE, Daley RJ, Jasper S (1977) Use of nuclepore filters for counting bacteria by fluorescence microscopy. Appl Environ Microbiol 33:1225-1228

Hobbie JE, Vallino JJ, Garrit RH, Buffam ID (1996) Availability of stream organic matter for estuarine biota. America Society for Limnology and Oceanography, Spring meeting, 1996, Milwaukee, WI

Ivarsson $\mathrm{H}$, Jansson M (1994a) Temporal variation of organic carbon in the river Öre, northern Sweden. Verh Internat Verein Limnol 25:1522-1525

Ivarsson $H$, Jansson $M$ (1994b) Temporal variations in the concentration and character of dissolved organic matter in a highly colored stream in the coastal zone of northern Sweden. Arch Hydrobiol 132:45-55

Jansson $M$, Blomqvist $P$, Jonsson A, Bergström AK (1996) Nutrient limitation of bacterioplankton, autotrophic and mixotrophic phytoplankton, and heterotrophic nanoplankton in Lake Örträsket. Limnol Oceanogr 41:1552-1559

Jansson $\mathrm{M}$, Bergström AK, Blomqvist $\mathrm{P}$, Isaksson $\mathrm{A}$, Jonsson $\mathrm{A}$ (1998) Impact of allochthonous organic carbon on microbial food web carbon dynamics and structure in Lake Örträsket. Arch Hydrobiol 144:409-428

Kirchman DL, Suzuki Y, Garside C, Ducklow HW (1991) High turnover rates of dissolved organic carbon during a spring phytoplankton bloom. Nature 352:612-614

Kuparinen J, Leonardsson L, Mattila J, Wikner J (1996) Food web structure and function in the Gulf of Bothnia, the Baltic Sea. Ambio Spec Rep No. 8:12-20

Leff LG, Meyer JL (1991) Biological availability of dissolved organic carbon along the Ogeechee River continuum. Limnol Oceanogr 36:315-323

McKnight DN, Aiken GR (1998) Sources and age of aquatic humus. In: Hessen DO, Tranvik LJ (eds) Aquatic humic substances. Ecology and biochemistry. Springer, Berlin, p 9-39

Editorial responsibility: David Karl,

Honolulu, Hawaii, USA
Moran MA, Hodson RE (1990) Bacterial production on humic and nonhumic components of dissolved organic carbon. Limnol Oceanogr 35:1744-1756

Moran MA, Hodson RE (1994) Support of bacterioplankton production by dissolved humic substances from three marine environments. Mar Ecol Prog Ser 110:241-247

Norland S (1993) The relationship between biomass and volume of bacteria. In: Kemp PF, Sherr BF, Sherr EB, Cole JJ (eds) Handbook of methods in aquatic microbial ecology. Lewis Publishers, Boca Raton, p 303-307

Norrman B (1993) Filtration of water samples for DOC studies. Mar Chem 41:239-242

Peltzer ET, Fry B, Doering PH, McKenna JH, Norrman B, Zweifel UL (1996) A comparison of methods for the measurement of dissolved organic carbon in natural waters. Mar Chem 54:85-96

Pettersson $C$ (1992) Properties of humic substances from groundwater and surface waters. Thesis, Dept of Water and Environmental Studies, Linköping University

Sholkowitz ER (1976) Flocculation of dissolved organic carbon and inorganic matter during the mixing of river water and seawater. Geochim Cosmochim Acta 40:831-845

Simon M, Azam F (1989) Protein content and protein synthesis rates of planktonic marine bacteria. Mar Ecol Prog Ser 51:201-213

Stockner JG, Klut ME, Cochlan WP (1989) Leaky filters: a waming to aquatic ecologists. Can J Fish Aquat Sci 47:16-23

Stumm W, Morgan JJ (1996) Chemical equilibria in natural waters. Wiley Interscience, New York

Søndergaard M, Middleboe M (1995) A cross-system analysis of labile dissolved organic carbon. Mar Ecol Prog Ser 118: $283-294$

Søndergaard M, Hansen B, Markager S (1995) Dynamics of dissolved organic carbon lability in a eutrophic lake. Limnol Oceanogr 40:46-54

Thurman EM (1985) Organic geochemistry of natural waters Nijhoff/Junk, Dordrecht

Tranvik LJ (1988) Availability of dissolved organic carbon for planktonic bacteria in oligotrophic lakes of different humic content. Microb Ecol 16:311-322

Tranvik LJ, Sieburth JM (1989) Effects of flocculated humic matter on free and attached pelagic microorganisms. Limnol Oceanogr 34:688-699

Zweifel UL, Norman B, Hagström $\AA$ (1993) Consumption of dissolved organic carbon by marine bacteria and demand for inorganic nutrients. Mar Ecol Prog Ser 101:23-32

Submitted: June 15, 1997; Accepted: November 24, 1998

Proofs received from author(s): June 4, 1999 